\title{
ACTIVE TEACHING FOR EFFECTIVE LEARNING - A TEACHER TRAINING MODEL WITH INFORMATION AND COMMUNICATION TECHNOLOGIES INTEGRATION
}

\author{
A.L. Rodrigues \\ Universidade de Lisboa, Instituto de Educação (PORTUGAL)
}

\begin{abstract}
Faced with the contemporary digital society and the need for pedagogical innovation, a renewal of teaching, assessment and learning methodologies is crucial. Active learning is one of the most appropriate teaching-learning methodologies, especially at the level of its potential for the development of skills and effective learning.

The purpose of this article is to present the main characteristics and principles of the Active Teacher Training model. This model will allow the implementation of innovative teaching-learning methodologies for the integration of digital technologies into teaching. It is based on identified pedagogical trends and was characterized by being organized according to the interests of the trainees, with flexible content management, shared planning and evaluation, supported by collaborative and cooperative work. This approach, of constructivist base, can also transfer skills to students which enable them to take responsibility for their own learning and creation of their own knowledge.

The aim is to analyze the implementation of this training model, namely at the level of the interconnection of teaching and learning methodologies with the evaluation process, underpinning the pedagogical integration of digital technologies in light of the weight they assume in contemporary society.

To this end, a case study was developed in a pre-service teacher training in Portugal, in a class of the Master's Degree in Teaching Economics and Accounting, of Institute of Education of University of Lisbon, in which this Active Training model was implemented during two school years.

The results point to the importance of the interconnection of teaching, evaluation and learning processes. This Active Teaching requires experimentation and integration of these processes, with formative feedback taking a significant role in achieving more effective learning. It was found that the participating teachers were able to develop skills and integrate digital technologies in their own teachinglearning process and could change their teaching practices.
\end{abstract}

Keywords: Active teacher training, training model, active learning, digital technologies integration, preservice teacher education.

\section{INTRODUCTION}

Digital technologies have revolutionized practically every aspect of our lives and work, "we live in an exponential times" [1] and it is fundamental in this complex digital landscape to face the challenges posed, especially those responsible for education, in order to enable students to participate fully in the economic, social and cultural life [2].

Accepting that "Technology can amplify great teaching but great technology cannot replace poor teaching" [2], it is clear that the adaptation and integration of DTs in the classroom of contemporary society's schools requires the adoption of new roles and forms of work by the teacher. It also requires reflection and analysis of the effects of this new relationship, with the training of teachers as a key factor in the process [3] [4].

It is clear that change is necessary, that schools need to reflect society and that there is a need to integrate digital technologies into educational practices. In this context an alternative and innovative model of teacher training, named Active Training (AT), was designed. It is based on theoretical concepts and identified pedagogical trends using innovative methods and processes of teaching, evaluation and learning that integrate digital technologies. The model is based on five structuring principles shown in Table 1. 
Table 1. Structuring Principles of Active Teacher Training

\begin{tabular}{|c|c|}
\hline Structuring Principles of AT & Concepts mobilized \\
\hline $\begin{array}{l}\text { Principle } 1 \\
\text { Cross-curricular training with integration into teaching } \\
\text { of digital technologies in an authentic social context } \\
\text { that supports human development. }\end{array}$ & $\begin{array}{l}\text { Transdisciplinary } \\
\text { Socio-constructivism } \\
\text { Authentic social context } \\
\text { On-the-job training }\end{array}$ \\
\hline $\begin{array}{l}\text { Principle } 2 \\
\text { Training tailored to the needs and interests of trainees, } \\
\text { differentiated and focused on skills, with flexible } \\
\text { planning and content management. }\end{array}$ & $\begin{array}{l}\text { Needs Analysis } \\
\text { Differentiated education } \\
\text { Skills } \\
\text { Flexible curriculum management }\end{array}$ \\
\hline $\begin{array}{l}\text { Principle } 3 \\
\text { Training based on a democratic and affective } \\
\text { pedagogical relationship, with the trainer as a guide, for } \\
\text { the critical and isomorphic reproduction of skills for } \\
\text { students. }\end{array}$ & $\begin{array}{l}\text { Democratic pedagogical relationship } \\
\text { Affectivity } \\
\text { Adult Education } \\
\text { Isomorphism }\end{array}$ \\
\hline $\begin{array}{l}\text { Principle } 4 \\
\text { Dynamic theoretical-practical training, supported by } \\
\text { collaborative and cooperative work in a learning } \\
\text { community, using active teaching methods and } \\
\text { strategies in synergy with digital technologies. }\end{array}$ & $\begin{array}{l}\text { Collaborative and cooperative work } \\
\text { Active methods } \\
\text { Project work } \\
\text { Group research or peer work } \\
\text { Flipped classroom }\end{array}$ \\
\hline $\begin{array}{l}\text { Principle } 5 \\
\text { Training for construction and development of skills of } \\
\text { thinking reflectively, acting autonomously, network } \\
\text { communication, participatory evaluation and self- } \\
\text { regulation, to create a community of practice that } \\
\text { allows the social construction of self-knowledge. }\end{array}$ & $\begin{array}{l}\text { Thinking reflectively } \\
\text { Acting autonomously } \\
\text { Connectivism } \\
\text { Evaluation and Self-regulation } \\
\text { Community of practice }\end{array}$ \\
\hline
\end{tabular}

This model, which enables active learning, allows simultaneous the implementation of innovative teaching-learning methodologies for the integration of digital technologies into teaching. It is based on identified pedagogical trends and was characterized by being organized according to the interests of the trainees, with flexible content management, shared planning and evaluation, supported by collaborative and cooperative work. This approach, of constructivist base, can also transfer skills to students which enable them to take responsibility for their own learning and creation of their own knowledge [5].

Principle 1, which is based on the concepts of Transdisciplinary, Socio-constructivism, Authentic social context and On-the-job training, states that AT is a methodology of cross-training, with the integration of digital technologies in teaching-learning processes, It can be developed with trainees from various curricular areas in an interdisciplinary way and above all through student-centered collaborative methodologies, based on a constructivist perspective. Given the relevance given to the social context and learning by doing, AT should be implemented in an authentic social context, that is, in the school itself, jointly allowing for integral and sustainable human development based on the idea of a school as a place of human development.

In light of the concepts mobilized, Needs analysis, Differentiated education, Skills and Flexible curriculum management, Principle 2 states that AT should be planned and organized according to learners' needs and interests, focusing individually on building and developing skills of students and trainees according to their profile, using strategies of pedagogical differentiation, especially considering 
the perspective of the teacher as a consultant. This differentiated teaching can be facilitated by flexible curriculum management based on learners' interests and learning needs.

Principle 3, mobilizing the concepts of Democratic pedagogical relationship, Affectivity, Adult Education and Isomorphism, states that AT should be based on a democratic and affective pedagogical relationship, related to a participative and cooperative environment, taking into account the eventual specificities of adult education that should privilege the usefulness of learning, the experience and its relation with reality. Also considering the trainer as advisor / consultant in the sense that trainees can reproduce critically and isomorphically the skills built and developed in practice later with their students.

Based on the concepts Collaborative and cooperative work, Active Methods, Project Work, Group Research or peer work and Flipped Classroom, Principle 4 states the promotion of facilitated collaborative and collaborative work, by the use of digital technologies in a learning community, with a strong use of methodologies and active teaching-learning strategies that promote the construction and development of diversified competences, in a movement that aims to be dynamic between theory and practice.

Principle 5, which is based on the concepts of Thinking reflectively, Acting autonomously, Connectivism, Evaluation and Self-regulation and Community of practice, reinforces the importance of research, construction and development of competences, namely reflexivity, autonomy and network communication applied to the integration of DT in teaching in the face of new digital environments. As well as the need for its assessment, proposing a participatory assessment, predominantly formative and self-regulating, interconnected with the teaching-learning process. It also aims to promote the creation of a community of practice for the pedagogical integration of DT in schools that interrelates learning with practice and allows the social construction of their own knowledge.

The model of Active Training arose from an investigation, started in 2014, and developed in workshops of in-service training of teachers that took place during the years 2015 and 2016. It also arose from work done in 2016-2018 of the Master's Degree in Teaching Economics and Accounting.

This study, conducted in Portugal, focused on the construction and development of teachers' skills, especially thinking reflectively, acting autonomously and increase digital skills, and on active methods and teaching strategies that integrate digital technologies.

After defining and experimenting with the AT model in different contexts, it was restructured to make it a more coherent training model. The main change was a more effective integration of assessment into the teaching-learning process.

\section{METHODOLOGY}

This research, based on a predominantly qualitative approach, proposes a training model and a specific strategies, Active Training (AT), that introduces new methods of teaching, assessment and learning integrating digital technology.

The case study method was applied, in specific Didactics and Professional Practice disciplines, in a class of seven students from a Masters in Teaching. The AT model was used, paying particular attention to the development of formative assessment integrated into the teaching and learning process [6] [7].

The teaching-assessment-learning strategies developed were: the analysis, presentation and discussion of texts and articles; the construction of learning scenarios; the elaboration of didactic materials and resources; the simulation of teaching-learning situations with participatory evaluation; observation and teaching of classes in a cooperating school; critical reflection on professional practice; and the performance of group work; using digital technologies for communication. All activities used formative evaluation with feedback.

The case study is a widely adopted method in research in education. It is used particularly when the researcher is confronted with complex situations in which it is difficult to select variables, but in which one tries to describe and analyze phenomena and their interactions [8].

Data collection consisted of a field diary through participant observation, learning scenarios carried out by the students, and photographic and video records. The participant observation, using a systematic record, consistently sought to present a high level of accuracy of the information and its analysis [9].

In this case study, the teaching-assessment-learning strategies developed in the initial seminars were: i) group presentations of scientific articles by the masters students with discussion in a large group, ii) 
the construction of learning scenarios of a curricular unit with materials and educational resources necessary for its development, and iii) evaluation tools.

In the subsequent seminars, the masters students did simulations of parts of these classes, with reflection and critical self-analysis on them. A chat session was also developed through Facebook with analysis and debate of a text. In the various activities referred to, the students were given continuous feedback, either oral, in the discussions, presentations and simulations of classes, or in written form.

In the subjects of Professional Practice, the masters students did coordinated work in the institution of higher education and in the cooperating schools. The field work in these schools involved the teaching of classes or parts of classes by a cooperating tutor. This included the preparation of a field diary describing and reflecting on the activities carried out.

The digital technologies associated to active methods were used in the strategies and the activities developed in the Masters in Teaching. They were integrated in an intensive way, be it in the distribution and organization of the work by the teacher, or in the work developed by the masters students. Different equipment was used, such as laptop, smartphone, and the FTELab room, and also various software and applications, namely Moodle, Facebook, Google Classroom, Prezi, Excel, Kahoot and Padlet.

\section{RESULTS}

In this study of in-service training it was found to be important teachers could see that the use of digital technology is effective, that it increases their freedom of action and allows them to check the progress made by students both inside and outside the classroom. Its use by teachers is also influenced by the motivation shown by their students. This may be a determining factor in the continued integration of digital technology.

This model of training, i.e. the construction and development of skills in teaching and learning linked with technology, provided the teachers with the opportunity to create their own knowledge, and to reflect on their teaching practices.

The most significant and constant constraint was the shortage of teachers' time and overwork in general. In the study of the pre-service teacher training, the trainees did all the work requested. It was confirmed:

1) that it was possible to differentiate groups according to the needs and interests of the trainees and to carry out the work in an authentic social context;

2) that it was possible to plan learning scenarios using active methods, based on collaborative work, which allowed the social construction of students' own knowledge;

3) diversified skills, namely digital, reflexive and self-regulation could be developed;

4) continuous evaluation supported by feedback could be established;

5) the critical and isomorphic reproduction of skills for their students, particularly digital skills, observed in the classes taught by the master's students in the cooperating schools.

The results point to the importance of the interconnection of teaching, evaluation and learning processes. This Active Teaching requires experimentation and integration of these processes, with formative feedback taking a significant role in achieving more effective learning.

\section{CONCLUSIONS}

In this research the main aspects in the design, construction and implementation of the Active Teacher training model for the integration of digital technology into teaching were analyzed. This verified the possibility of developing innovative teaching methods and strategies used by teachers.

For future applications it is essential to note some issues for research. There is the need to find time and resources for teachers to develop their skills and to integrate digital technology into their teaching.

It was found that the participating teachers were able to develop skills and integrate digital technologies in their own teaching-learning process and could change their teaching practices. 


\section{REFERENCES}

[1] P. Mishra, M. Koehler, and D. Henriksen, "The Seven Trans-Disciplinary Habits of Mind: Extending the TPACK Framework towards 21st Century Learning", in Educational Technology, vol. 51, no. 2, pp. 22-28, 2011. Retrieved from http://citeseerx.ist.psu.edu/viewdoc/download?doi=10.1.1.701.4293\&rep=rep1\&type=pdf.

[2] OECD, Students, Computers and Learning: Making the Connection, PISA, OECD Publishing, 2015. Retrieved from http://dx.doi.org/10.1787/9789264239555-en.

[3] K. Goeman, J. Elen, B. Pynoo, and J. Braak, "Time for action! ICT Integration in Formal Education: Key Findings from a Region-wide Follow-up Monitor", in TechTrends, vol. 59, no. 5, pp. 40-50, Association for Educational Communications and Technology, 2015. Retrieved from https://doi.org/10.1007/s11528-015-0890-6.

[4] L. Johnson, S. Adams-Becker, V. Estrada, A. Freeman, P. Kampylis, R. Vuorikari, and Y. Punie, Horizon Report Europe: 2014 Schools Edition. Luxembourg: Publications Office of the European Union \& Austin, Texas: The New Media Consortium, 2014. Retrieved from https://ec.europa.eu/jrc/sites/default/files/horizon_report_eu_pt.pdf.

[5] A. L. Rodrigues, $A$ formação ativa de professores com integração pedagógica das tecnologias digitais (Tese de doutoramento). Instituto de Educação da Universidade de Lisboa, 2017. Retrieved from http://repositorio.ul.pt/handle/10451/28329.

[6] D. Fernandes, "Para uma teoria da avaliação formativa", in Revista Portuguesa de Educação, vol. 19, no. 2, pp. 21-50, 2006. Retrieved from http://hdl.handle.net/10451/5495.

[7] A. Nóvoa, F. Marcelino, and J.R. Ó, (Orgs.), Sérgio Niza. Escritos sobre educação. Lisboa: Tinta-da-china, 2012.

[8] R. Yin, Case Study Research: Design and Methods (2 $2^{\text {nd }}$ ed). Thousand Oaks, CA: SAGE Publications, 1994.

[9] R. Bogdan and S. Biklen, Qualitative Research for Education: An Introduction to Theories and Methods ( $5^{\text {th }}$ ed.). Pearson, 2007.

Rodrigues, A. L. (2019). Active teaching for effective learning - a teacher training model with information and communication technologies integration. Proceedings of ICERI2019, The 12th Annual International Conference of Education, Research and Innovation (pp. 4767-4771). Seville (Spain), 11th, 12th and 13th of November 2019. doi: 10.21125/iceri.2019 